\title{
Mobile Devices Applied in Self-Studying English as a Foreign Language Among Non-Native Students in Vietnam and Japan
}

\author{
https://doi.org/10.3991/ijim.v15i09.19993
}

\author{
Nguyen Thi Thanh Thuy ${ }^{(\varpi)}$, Takashi Yukawa \\ Nagaoka University of Technology, Niigata, Japan \\ s1870120stn.nagaokaut.ac.jp
}

\begin{abstract}
In the era of technology, learning can be supported with mobile devices inside and outside of the classroom. In the hope of taking advantage of technology advances, teachers worldwide have integrated technologies into teaching to effectively deliver lesson content and address students' needs. However, few non-native learners are exposed to mobile devices to optimize selfstudying English outside the classroom. Thus, the present paper conducts a case study to look into mobile devices' applications to enhance self-studying English as a foreign language. The study participants included 26 Japanese and Vietnamese learners divided into two groups over 15 weeks. Quantitative and qualitative methods were used to analyze and compare the results with R-Studio statistics software. The present study sought to encourage collaboration and foster the autonomy of learners with mobile devices' assistance as supporting language selflearning tools. The findings of the present research will be discussed in terms of the efficiency and potentials of mobile devices as supportive tools outside of classroom activities among Vietnamese and Japanese students as non-native learners of English.
\end{abstract}

Keywords - Non-native learners, mobile devices, self-study EFL, positive attitudes, potentials

\section{Introduction}

Information communication technology (ICT) emphasizes communication in modern information technology, transmission or transfer of information from place to place and over a distance. The fast and increasingly natural adoption of handheld devices such as smartphones and tablets into everyday life is also believed to have vast potentials for foreign language learning. There are several potential benefits of mobile learning adoption to learners. One of the main advantages is the affordability that comes with mobile devices [1]. Compared to more robust technologies, such as desktop computers, mobile devices prices are much lower.

Moreover, the efficiency of accessing the information on the go is one of the benefits to learners [2]. Convenience can be attributed to the fact that the learner does not need 
to be confined to a specific location to learn. Learning can take place at any place and at any time [3].

In this sense, the United Nations Educational, Scientific and Cultural Organization (UNESCO) gives prominence to mobile technologies, characterized by the use of tablets, iPads, portable book devices, game consoles, and, especially, smartphones, defining mobile devices as "digital, easily portable, owned and controlled by an individual rather than an institution, with access to the internet and multimedia aspects, capable of facilitating a large number of tasks, particularly those related to communication" [4].

To date, several studies have reported how mobile technology assists language learning, and numerous advantages of mobile technology for language learning have been reported $[5,6,7,8]$. In the hope of taking advantage of technology advances, teachers worldwide have implemented ICT in the classroom to deliver lessons and address the needs of students effectively. Learning can be supported with mobile devices inside and outside of the classroom [6]. Smartphones are primarily used to develop student learning performance in different fields of study [9].

The significance of English language education in non-English speaking countries such as Japan [10] and Vietnam [11,12] in the $21^{\text {st }}$ century is undeniable. Lai pointed out that "a majority of research in the English language learning field has been focusing largely on teaching or course effectiveness, but little has been done to look at what makes learners self-determined enough to take control of their learning, and the factors that differentiate successful and less successful self-access users" [13]. According to most teachers and researchers, motivation is believed to be a significant driving force of successful language learning [14]. In Japan, English learning motivation has been an important research topic for many years, under the era of high-tech integration [15]. However, Japanese students do not exhibit increased language skills and do not seem highly motivated to learn English despite their current emphasis on English education $[16,17]$. Vietnamese students are facing a similar situation as non-native learners coming from a developing country [13]. Using multimedia in the classroom makes a lesson more exciting and motivates students to be more attentive [10]. Mobile devices have an immense potential to enrich the teaching and learning experience [18]. Hence, it is essential for technology to be applied within the formal and informal learning environments to improve educational outcomes [19]. However, there has not been a variety of research into the thorough use of mobile tools to study and self-study English as a foreign language among non-native English-speaking learners outside the classroom. Research into this field is still scarce.

The purpose of the present study is to further the findings in language self-studying with mobile device assistance by examining the effects that mobile devices may have on non-native students' attitudes towards English as a foreign language (EFL) self-studying.

\section{Review of Literature}

Language learning is fundamentally a socio-cultural experience. In the last few decades, ICT integration and applications have shaped how language is taught and learned. 


\subsection{Role of information and communication technology in language learning}

Information and communication technology is the term used most often in the current educational setting to describe how technology, in general, is used and applied to teaching and learning. In recent years, ICT has influenced how language is taught and learned. The advancement of ICT has brought about a revolution in entire industries' business practices and strategies, significantly higher education policy, and performance [20]. There is a growing interest in using mobile devices to learn the English language, and using mobile learning has a significant impact on English language learning [21].

Space and locations for language learning have grown tremendously in terms of technology as well [22]. Given the impact of ICT on our lives and the advantages it affords society daily, it is unsurprising that ICT can be used to learn the English language. Computers and other tools have been useful supporting tools for EFL learners [23]. Technology has become integral to how most language learners worldwide access materials in their second, foreign language or interact with others inside and outside the classroom [24]. Technology has allowed us to situate learners within more extensive connected networks and move away from traditional teaching approaches. This enables students to develop as autonomous learners.

\subsection{A move to mobile-assisted language learning}

The rapid change in numerous mobile devices, such as the smartphone display, on the market, has led to changes in how we understand learning. Mobile-assisted language learning (MALL) has become one of the most heatedly discussed topics among educators and researchers as a growing field of interest. Mobile learning is a branch of ICT in education. The ubiquity of mobile devices possibly supports student access to learning materials anytime and anywhere, leading to increased contact with both formal and informal learning [25]. Another study stated that mobile learning (M-learning) is being used extensively in teaching and learning foreign languages, which further widens learners' mobility [26].

Various innovative teaching practices have been reported across the globe in the past decade. Furthermore, with more educators realizing the value of out-of-class learning, more studies on promoting out-of-class learning have been conducted, including studies on vocabulary learning, the four necessary language skills [27], and learner autonomy [28].

Concerning language learning, Kukulska-Hulme, Lee, and Norris incorporated formal and lifelong learning concepts, which makes mobile learning extremely valuable in terms of classroom affordability [29]. The use of mobile devices in learning requires effective learning design and more self-determination on the part of the learners themselves.

Pedagogical theories and a teaching framework can be appropriately integrated into the shift in technologies [30]. Prominent researchers focus on learners' distinctive prospects and mobility in formal and informal educational settings to explicate the characteristics and elements of mobile learning [31,32,33,34,35]. 
Mobile learning has paved the way for ubiquitous learning. Many students are now familiar with using personally owned, portable digital devices that can connect with the assistance of technology integrated [36]. Mobile-assisted language learning supports many language learning areas, such as vocabulary, comprehension, speaking, listening, and writing skills. When compared to traditional classroom lessons, mobile learning brought about ease of use, comfort, and excitement, along with innovation for learners [37]. Therefore, learners expressed high interest in the use, involvement, and productivity [38].

Students have more choices to learn within a learning environment that offers adaptability to their individual needs and learning styles and the flexibility of computer systems. Learning can unfold in a variety of ways. People can use mobile devices to access educational resources, connect with others, or create content, both inside and outside the classroom.

Computer-assisted and mobile-assisted technologies' pervasiveness has primarily influenced the current state of foreign language education. In that context, mobile devices should be recognized as a supporting tool for non-native learners of EFL. The availability of technological tools helps to ensure the development of learner autonomy.

\section{Methodology}

Qualitative and quantitative data were collected from questionnaires sent to the participants before and after the mobile learning application, on-going observation, and interviews during the 15 -week course.

The course delivery is described as follows:

Weeks 1 and 2:

- A placement test to provide an overview of the English proficiency of the participant: Q Placement Tests

- Pre-treatment surveys to determine the use of mobile devices in learning EFL inside and outside of the classroom

- Introduction to the application of mobile devices to self-study EFL outside of the classroom

Weeks 3 through 14:

- Instructions and discussion of using mobile devices (laptops/ smartphones/ iPads/ tablets): habits, frequencies, and attitudes

- Surveys and interviews to study participant habits and frequencies of using mobile devices in self-studying EFL

- Discussion of learning and dealing with any difficulties or problems via an internal messaging platform (Slack) 
Week 15:

- Post-treatment surveys and interviews about the preference of using mobile devices and attitudes towards self-studying EFL with mobile devices

- Results and Comparisons

Cronbach's alpha correlation coefficient was computed to assess the instrument's reliability as pre-and post-questionnaires given to learners during the project period. The results obtained from this test indicate the average Cronbach's alpha based on the collected data regarding the participants' habits in using mobile devices and the attitudes toward the use of mobile devices in ELF self-studying. Three-dimensional reliability analysis showed that the Cronbach's coefficient for mobile devices used in learning (1), mobile devices used in self-learning EFL (2), and the attitudes towards using mobile devices in self-learning EFL (3) were 0.69, 0.65, and 0.70, respectively. The total correlation was 0.68 , which is $\geq 0.3$, proving that the reliability of the subjects collected is acceptable, as shown in Table 1 [39]. Thus, the internal consistency is adequate, and the desired reliability of the measurements is expected to be satisfactory.

Table 1. Cronbach's alpha

\begin{tabular}{|l|c|}
\hline \multicolumn{1}{|c|}{ Variables } & Cronbach Alpha Value \\
\hline Students' use mobile devices in learning (1) & 0.69 \\
\hline Students' use mobile devices in self-learning English as a foreign language (2) & 0.65 \\
\hline $\begin{array}{l}\text { Students' attitudes towards using their mobile devices in self-learning English } \\
\text { (3) }\end{array}$ & 0.70 \\
\hline Total & $\mathbf{0 . 6 8}$ \\
\hline
\end{tabular}

Quantitative questionnaires were delivered to the selected students, and data were collected and subsequently analyzed by R-studio statistics software.

Moreover, qualitative interaction and discussions were conducted via Slack chatroom, which was internally used among surveyed learners during the project. A further explanation and requests for other learning materials were uploaded on the user-friendly Slack chatroom. Bi-weekly tests assessed learner progress, and a final term test was used to analyze the participants' proficiency after the entire course.

\subsection{Research questions}

The present study attempts to determine mobile device general habits of users who have their device language set to Vietnamese or Japanese. Thus, a comparative outlook is to generalize mobile devices' use in self-studying English as a foreign language from the perspectives of non-native learners in Vietnam and Japan. After that, attitudes towards mobile devices will reveal the preferences and imply possibilities of integrating into language self-learning outside of the classroom for non-native learners. Research questions are as follows: 
1. How do the participants apply mobile devices to self-studying English as a foreign language in their home country?

2. How do the participants react to mobile devices' application in self-studying EFL outside of the classroom?

3. What contributions can the present study make to language proficiency enhancement and the EFL learning process?

\subsection{Samples of participants}

In the present study, we recruited quantitative and qualitative data from 26 students in total, including thirteen Japanese learners and thirteen Vietnamese participants. Table 2 describes participants' demographic characteristics, including the gender, year group, and English learning experience of the participants.

Table 2. Demographic characteristics of participants

\begin{tabular}{|l|l|l|}
\hline \multicolumn{1}{|c|}{ Nationality } & \multicolumn{1}{|c|}{ Gender } & \multicolumn{1}{c|}{ Experience in learning English } \\
\hline \multirow{3}{*}{ Japanese } & Female: $1(7.69 \%)$ & $\begin{array}{l}\text { Less than 5 years: 3 }(23.08 \%) \\
\text { More than 5 years: 9 }(69.23 \%) \\
\text { More than 10 years: } 1(7.69 \%)\end{array}$ \\
\cline { 2 - 3 } & Male: $12(92.31 \%)$ & $\begin{array}{l}\text { Less than 5 years: 0 }(0 \%) \\
\text { Vietnamese }\end{array}$ \\
\cline { 2 - 3 } & Female: 9 & $\begin{array}{l}\text { More than 5 years: } 12(92.31 \%) \\
\text { More than 10 years: } 1(7.69 \%)\end{array}$ \\
\cline { 2 - 3 } & Male: $4(23.08 \%)$ &
\end{tabular}

Table 3. Scores of the pre-treatment placement test for general English proficiency

\begin{tabular}{|c|c|c|c|c|}
\hline $\begin{array}{c}\text { Scores achieved } \\
\text { (out of } 100 \% \text { ) }\end{array}$ & Writing & Reading & Speaking & Listening \\
\hline$<20 \%$ & 4 students $(15.38 \%)$ & 3 students $(11.54 \%)$ & 13 students $(50.00 \%)$ & 3 students $(11.54 \%)$ \\
\hline $20 \%-30 \%$ & 17 students $(65.38 \%)$ & 20 students $(76.92 \%)$ & 9 students $(34.62 \%)$ & 3 students \\
\hline $31 \%-40 \%$ & 5 students $(19.23 \%)$ & 2 students $(7.69 \%)$ & 3 students (11.54\%) & 9 students $(34.62 \%)$ \\
\hline $41 \%-50 \%$ & 0 student & 1 student $(3.85 \%)$ & 1 student $(3.85 \%)$ & 11 students $(42.31 \%)$ \\
\hline $51 \%-60 \%$ & 0 student & 0 student & 0 student & 0 student \\
\hline
\end{tabular}

A placement test was provided to all participants before starting the project to obtain an overview of English proficiency. The results shown in Table 3 were collected based on the average calculation for a $100 \%$ full score test. Average scores for the four basic skills, including listening, writing, reading, and speaking, were mainly under $40 \%$ of the total points, divided into four levels, ranging from less than $20 \%$ to between $51 \%$ and $60 \%$. As shown in Table 3, most of the students scored $20 \%$ to $30 \%$ of the test scores for writing $(65.38 \%)$, reading $(76.92 \%)$, and speaking $(34.62 \%)$. Listening had a significantly higher percentage, with 11 students achieving $41 \%$ to $50 \%$, while only one student scored in this range in reading and speaking. No student scored over $51 \%$ on the initial test. This indicates that all the participants fell into a similar group of low English level and sought a particular level of_improvement within the 15 weeks of the pilot study. 


\subsection{Data collection instruments}

Data collected from two separate questionnaires were analyzed with R-studio software. A pre-treatment survey was given to 26 students after they had completed four English tests of writing, reading, listening, and speaking based on the Q Placement Tests, which were designed to place students into the appropriate strand and level of Q: Skills for Success $[40,41]$.

The Reading and Writing Placement Test measures reading comprehension, other reading skills, vocabulary knowledge, vocabulary skills, grammar, and writing skills. The Reading and Writing Placement Test consists of 50 items. The Listening and Speaking Placement Test measures listening comprehension, other listening skills, vocabulary knowledge, vocabulary skills, grammar, pronunciation, and speaking skills. The Listening and Speaking Placement Test consists of 50 items. There are various item types: multiple-choice, fill-in-the-blank, sentence completion, paragraph completion, error identification and correction, sentence rewriting, sentence construction, matching, true/false, and sequencing.

In addition to face-to-face class meetings, participants also joined an internal chatroom created on the Slack platform (Figure 1), mainly used for further discussion, requests, explanations, and general announcements outside of the classroom.

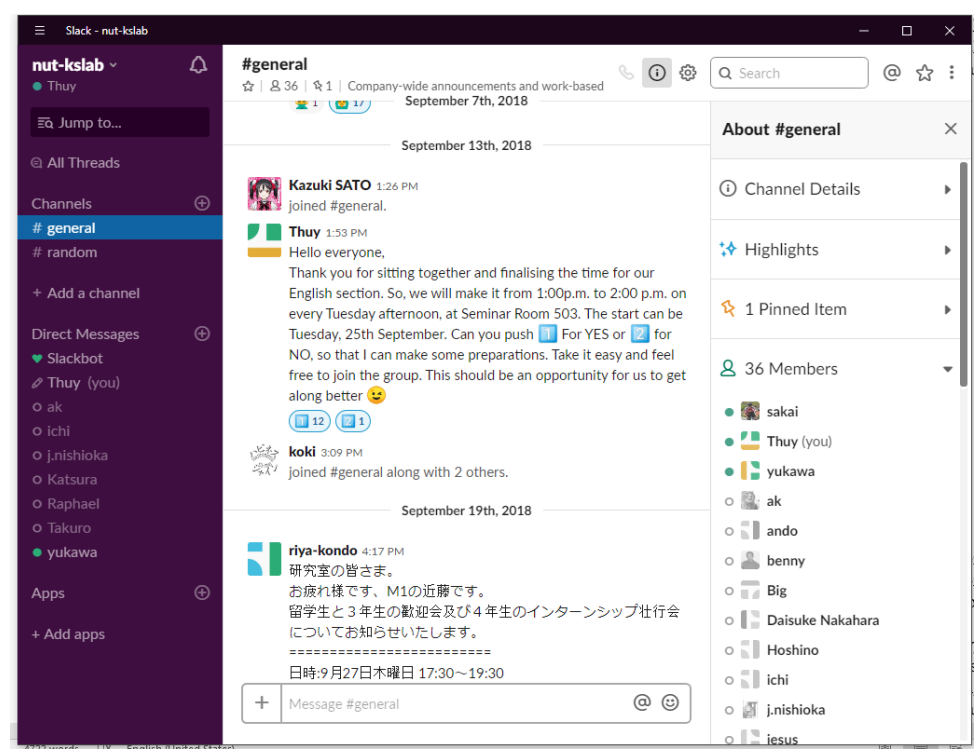

Fig. 1. The interface of an internally used Slack chatroom

A free version of the Slack chatroom was used in the present study. Slack works as a collaboration hub in which team members can unite and the necessary members can advance the project while confirming necessary information on time and with the necessary tools. 
Pre-treatment and post-treatment questionnaires were created to study the use of mobile devices in studying English as a foreign language outside the classroom.

\section{$4 \quad$ Findings and Discussion}

\subsection{How do the participants apply mobile devices to self-studying English as a foreign language in their home country?}

To answer research question 1, the habits and frequencies for using mobile devices to study English and self-study of English among non-native learners will be discussed in this section.

Figure 2 gives a detailed description of ten different habits in using mobile devices regularly, ranging from daily to none (never), among Vietnamese and Japanese learners. Significantly, $69 \%$ of students reported using mobile devices to look up new vocabulary as the significant function of an online or electronic dictionary. A total of 18 students used online dictionaries to search for the vocabulary regarding meaning, usage, and pronunciation of words. Playing interactive vocabulary games in English was the primary benefit students chose every month ( $85 \%$ of the learners). The remaining $15 \%$ of the students reported mobile devices were used weekly based on their weekly English lessons under their teachers' instructions. However, no students used mobile devices to play games in English to study English daily further. Interestingly, 18 students (69\%) said that they used their mobile devices, i.e., smartphones, to record English lessons or lectures at class for later use as explanation and revision after class every week.

As shown in Figure 2, all of the surveyed participants used mobile devices at least once or twice on a monthly, weekly, or daily basis to engage in self-studying of English. However, ten out of the 26 students (38\%) never communicated with foreigners via social networks, whereas 16 of them chose to connect online with foreigners to practice English speaking skills monthly. No student reported using mobile devices to gain international connections for English study weekly or daily. This low frequency of nonnative learners regarding interaction with native speakers online indicated that non-native participants had not taken advantage of social networking via mobile devices very often.

Most of the students used mobile devices for various purposes on a monthly and weekly basis according to the class schedule and the appearance of English lessons, and the instructor's requirements.

Figure 2 illustrates the exact percentages of the frequencies at which the participants used mobile devices. Each variance was set with a value in order to be computed with R-studio calculations. Table 4 shows a more specific division of frequencies to give a more detailed analysis based on participant responses. 


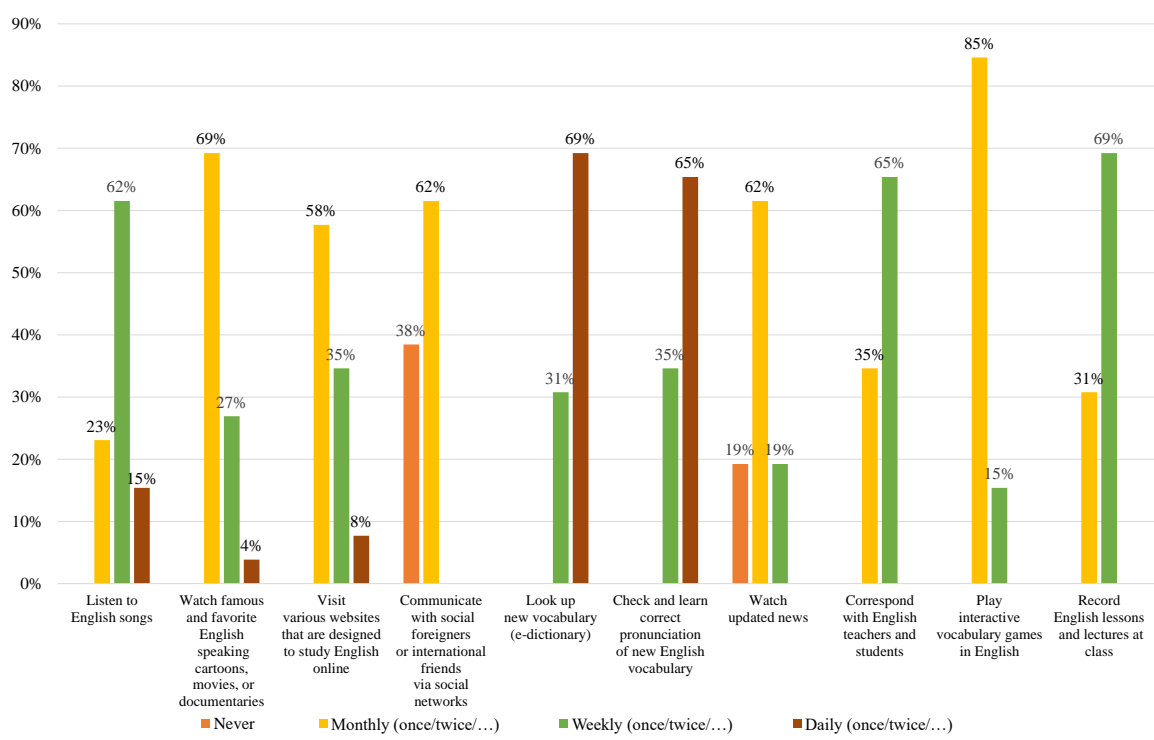

Fig. 2. Habits and frequencies of using mobile devices in self-studying English

Table 4 shows high mean scores belonging to the groups of monthly and weekly levels with $22.69 \%$ and $20.39 \%$ on average, respectively, which confirms the parallel equivalence of frequencies in using mobile devices from the questionnaire results. As shown in Figure 2, the number of students using mobile devices is scattered in every mobile use section weekly. More than $60 \%$ of the participants listened to English songs in correspondence with English teachers and students or recorded English lessons and lectures in class at least once a week. Besides, these groups' standard deviation was relatively low among the results, which indicated consistency among the answers of Japanese students regarding the frequent use of mobile devices on a weekly $(10.96 \%)$ or monthly $(14.14 \%)$ basis.

Table 4. Item statistics - The level of frequencies

\begin{tabular}{|l|c|c|c|}
\hline \multicolumn{1}{|c|}{ Level of Frequencies } & Mean & Std. Deviation & N \\
\hline Never & $5.38 \%$ & $8.15 \%$ & 26 \\
\hline Monthly (once/twice/...) & $22.69 \%$ & $14.14 \%$ & 26 \\
\hline Weekly (once/twice/...) & $20.39 \%$ & $10.96 \%$ & 26 \\
\hline Daily (once/twice/...) & $8.46 \%$ & $19.34 \%$ & 26 \\
\hline
\end{tabular}

\subsection{How do the participants react to mobile devices' use in self-studying EFL} outside of the classroom?

In this section, different levels of agreement depict participant reactions to mobile devices' application in self-studying EFL. Besides, the learners' preference for mobile devices reflects deeper attitudes toward this application in EFL self-studying for nonnative English speakers. 


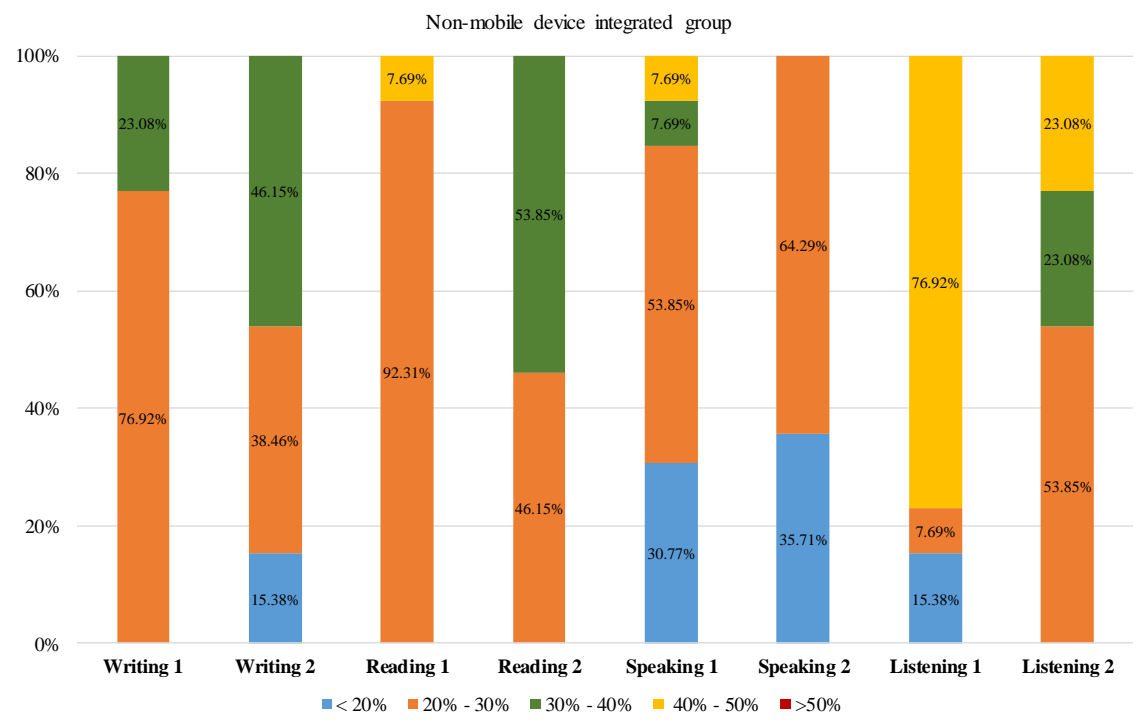

Fig. 3. Test scores before and after integrating mobile devices into self-studying English as a foreign language (EFL) of control groups (without mobile devices)

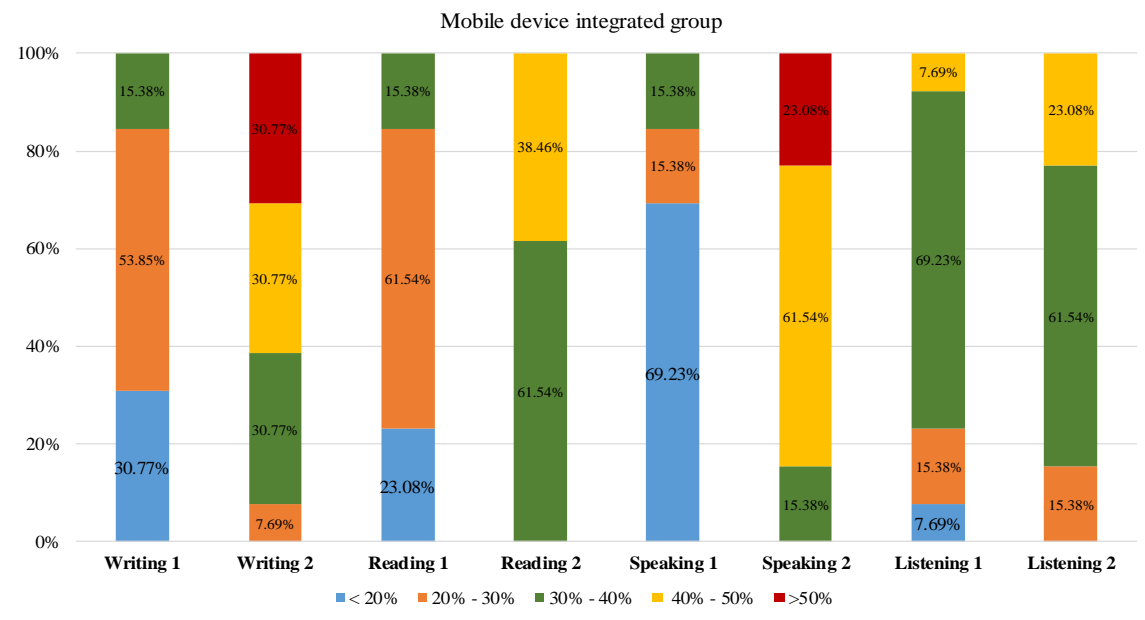

Fig. 4. Test scores before and after integrating mobile devices into self-studying EFL of subject groups (with mobile devices)

The large ownership of smartphones has triggered educators to consider integrating portable technological devices in everyday language learning in face-to-face [42] and distance learning [43]. With the hope of enhancement in self-studying EFL, non-native English learners were encouraged to use mobile devices, i.e., smartphones, laptops, and/or computers, from the researchers' supporting requirement. The level of agreement with mobile devices' use agreed well with the results of the test scores in Table 3 , 
reflecting the test scores before and after mobile device integration of the sampled population in the present study. An expected increase in the final scores after applying mobile devices to self-studying EFL revealed a positive enhancement in learner outcomes after the 15-week pilot course.

Figures 3 and 4 depict the comparison of four skill tests before and after the 15-week course according to the control group without being integrated with mobile devices and the subject group integrated with mobile devices, respectively. All four columns with expressions labeled 1 with the skills show the pre-treatment test results, and the expressions labeled 2 indicate the post-treatment test scores. Each skill is paired as 1 and 2, respectively, for a before and after comparison to being observed following the achieved scores ranging from less than $20 \%$ to $51 \%$ to $61 \%$.

As shown in Figure 3, for the control group of learners who did not use mobile devices to self-study EFL, none of the participants earned more than 50/100 after 15 weeks. Generally, the students gained a slight enhancement in the post-treatment tests, with $46.15 \%, 53.85 \%$, and $23.08 \%$ of the learners scoring $30 \%$ to $40 \%$ for writing 2 , reading 2 , and listening 2 , respectively. In the speaking skill, however, no learner scored $30 \%$ to $40 \%$, even though two students scored $30 \%$ to $50 \%$ out of $100 \%$ in a previous course: $30 \%$ to $40 \%$ (one student) and $40 \%$ to $50 \%$ (one student). The interviewers later reported that, in reality, electronic dictionaries are mainly used while self-studying EFL on learner mobile devices. However, the control group, which did not use mobile devices, could neither look up new words nor search for useful language phrases. Therefore, this deterred the learners from enhancing their language skills. The control group was asked not to use mobile devices in the process of self-studying EFL. Even though the post-test results revealed improved scores in most skill areas, the control group did not significantly increase scores achieved as the subject group, which used mobile devices in self-study EFL.

Having a closer look at Figure 4, which demonstrates the subject group results, $30.77 \%$ and $23.08 \%$ of the learners were able to score up to $>50 \%$ for writing 2 and speaking 2. Such an enhancement was not observed in the control group in Figure 3. The majority of learners achieved a score of between $30 \%$ and $40 \%$ of the total scores in writing $2(30.77 \%)$, reading $2(61.54 \%)$, and listening $2(61.54 \%)$. More interestingly, in the subject group, all of the participants achieved scores higher than $20 \%$ in all four skills, and no one fell into the group scoring less than $20 \%$.

This evidence proved that with mobile devices integrated, non-native learners could enhance their EFL post-test scores and language skills. This was later confirmed by three interviewees, who scored $>50 \%$ and stated that "mobile devices helped them to look up new vocabulary or specific terms that they are not acquainted with" (Student 1). The other student said that he could check and correct his pronunciation and speak out the words correctly by using mobile devices. Hence, he gained more confidence in speaking English. The third student also showed his habit of using mobile devices to study English via popular English songs or play interactive vocabulary games designed by his teacher. 


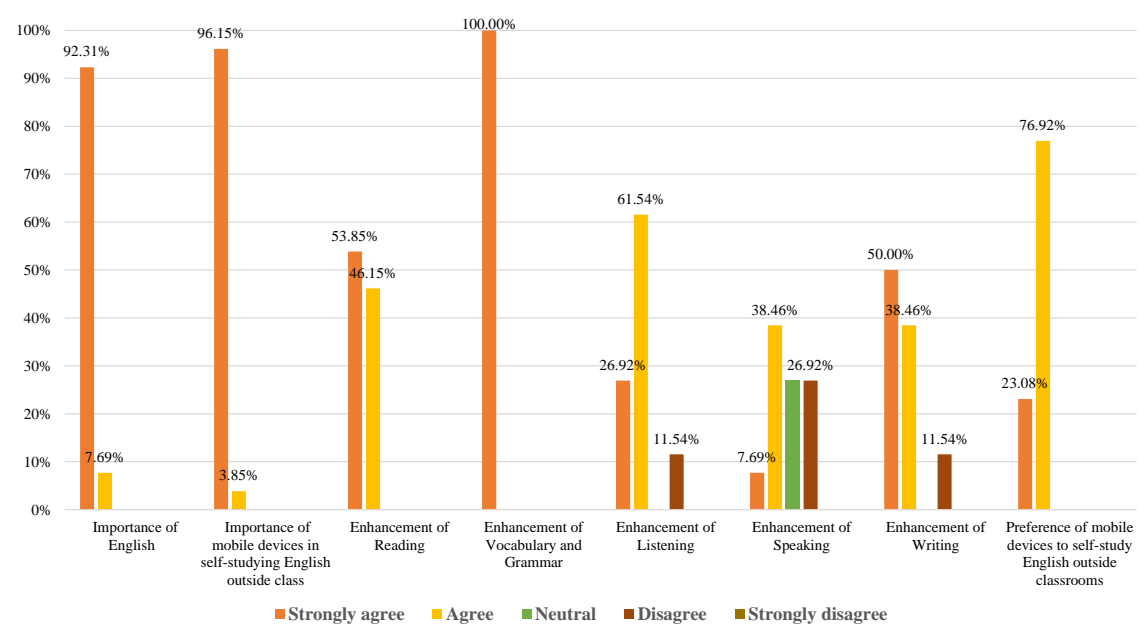

Fig. 5. Attitudes of learners towards using mobile devices in self-studying EFL

The results were not far from expected, with a significant improvement in the total final scores, but this slight increase illustrated the possibility of positive enhancement in mobile device integration in self-studying EFL among non-native learners.

Figure 5 shows the agreement levels for using mobile devices in self-studying English as a foreign language among Vietnamese and Japanese learners. This result was collected from a 5-point Likert scale questionnaire comprising 23 questions summarized in nine sections. The original version, which consisted of 23 questions, was designed to express the learner's extent in using mobile devices for particular purposes. For data analysis, this questionnaire was re-categorized and re-classified into nine main areas concerning the learners' concise feedback. As shown in Figure 5, all of the participants came to the final decision to acknowledge the importance of English and that of mobile devices in self-studying EFL, and $92.31 \%$ and $96.15 \%$, respectively, of the students, agreed with these opinions. As mentioned earlier in the habits of applying mobile devices into self-studying EFL (Figure 2), in this continuous survey, $100 \%$ of the students strongly agreed that integrating mobile devices into self-studying of EFL enhances vocabulary size and grammar study.

Figure 5 shows that all participants finally agreed with the integration of mobile devices to enhance their reading, vocabulary-grammar, listening, speaking, and writing skills. However, regarding listening, speaking, and writing outcomes, learners indicated their disagreement with the belief that mobile devices improved their language skills, but at lower percentages than the relevant agreement levels, i.e., $11.54 \%, 26.92 \%$, and $11.54 \%$ of students disagreed. Students reported later in the interviews that they hardly made use of mobile devices in practicing listening, speaking, or writing English because of the limited sizes of their smartphones' interfaces, which are smaller than laptop or desktop computer screens. This prevented students from using cell phones more often or talking, chatting, or writing in the classroom. In terms of speaking, students preferred to practice face-to-face with other people to increase their confidence in communicative interaction. Furthermore, a human can recognize and correct pronunciation or speaking 
mistakes more accurately than a machine. Overall, both Japanese and Vietnamese participants expressed high preferences for using mobile devices in self-studying EFL outside of the classroom, with $23.08 \%$ and $76.92 \%$ of participants strongly agreeing or agreeing with the use of mobile devices in self-studying EFL.

Table 5. Item statistics - the level of agreement

\begin{tabular}{|l|c|c|c|}
\hline \multicolumn{1}{|c|}{ Level of Agreement } & Mean & Std. Deviation & N \\
\hline Strongly agree & $23.93 \%$ & $29.65 \%$ & 26 \\
\hline Agree & $43.59 \%$ & $12.16 \%$ & 26 \\
\hline Neutral & $24.79 \%$ & $21.68 \%$ & 26 \\
\hline Disagree & $7.69 \%$ & $9.42 \%$ & 26 \\
\hline Strongly disagree & $0 \%$ & $0 \%$ & 26 \\
\hline
\end{tabular}

According to the descriptive statistics in Table 5 analyzed by R-Studio, the mean and standard deviation reinforced the questionnaires' results for higher reliability regarding the agreement level on the use of mobile devices in learning English and selfstudy English.

As shown in Table 5, most participants agreed to use mobile devices to learn and study English outside of the classroom. The highest mean item, i.e., Agree (43.59\%), with the lowest standard deviation (12.16\%), confirmed the consistency of students' answers and the levels of their agreement in mobile learning use for foreign language study and self-study. Similarly, the mean and standard deviation of students disagreeing with the use of mobile devices in self-studying English was $7.69 \%$ and $9.42 \%$, respectively. No student strongly disagreed with mobile devices used in the process of selfstudying EFL outside of the classroom.

\subsection{Contributions to language proficiency enhancement for non-native learners by using mobile devices in self-studying EFL}

The present study makes four main contributions. First, current state-of-the-art studies on mobile language learning were more deeply analyzed, and mobile learning application to self-study English as a foreign language by non-native English-speaking students was investigated in terms of practical preferences. Vietnamese and Japanese learners reported they rarely used mobile devices to study English outside of the classroom. Hence, a week was necessary for students to get used to time management when introduced to this application when self-studying EFL at home. Second, the present study reveals Vietnamese and Japanese learners' habits and attitudes toward the use of mobile devices in self-studying English outside of the classroom. Non-native learners' attitudes and preferences toward mobile learning were confirmed to be strongly similar to each other. The students would like to use mobile devices more often, which led to higher positives in mobile use attitudes to self-study EFL. Furthermore, mobile learning benefits led to strong and positive preferences for using mobile devices to self-study English. These results provide potentially useful information for teachers, learners, educators, and researchers in this new era of teaching and learning foreign languages with mobile assistance. Teachers should aim to facilitate learning in class using instructional technology in foreign language learning, and as such, they are encouraged to modify 
the use of convenient mobile devices that students own to make use of technological applications. In this way, tech tools can become user-friendly companions for students when they are not under the observation of a teacher or in a formal classroom setting. Finally, self-study is therefore highly enhanced in terms of the autonomy, motivation, and learning strategies of non-native learners [44]. Learners are believed to lack learning skills and strategies due to social networking distraction when using mobile devices. Amiri and Branch explained that technological devices should always be used by students and teachers [45] and integrated into the learning curriculum [46].

Teachers play a crucial role in the implementation of new technologies in the classroom $[47,48]$. Teachers' perceptions concerning the impact of mobile technology on learning reflect their beliefs about how this technology influences learning processes $[47,49]$. Under instructions from teachers, learners can also gain more awareness of how to learn and acquire English as a foreign language on their own. Furthermore, learning how to use new forms of technology is essential because it encourages learners to innovate and transfer knowledge effectively through their knowledge and skills [50,51]. The significance of high preference for the integration of mobile devices revealed positive potentials for mobile devices as an assist to study and enhance language skills outside of the classroom.

\section{Conclusion}

The present study adds to existing research on mobile device use in language teaching and learning among non-native English-speaking students, specifically Japanese and Vietnamese students. Language self-study tools are essential for helping non-native learners acquire languages in a more effective and time-saving manner. This can allow learners to benefit from linguistic and communicative accomplishments internationally, as English use has gained popularity.

As for educators, mobile devices should be positively encouraged in classrooms instead of restricting students from using mobile devices. This approach should be observed, regulated, and adjusted regularly to reap the educational benefits of mobile device use without abusing this privilege. Even though students often engage with online media independently, a better understanding of the affordances of various modes of linguistic input for different aspects of language acquisition could help both learners and teachers to identify the most effective ways of reaching particular learning goals.

The limitations of the present research are a relatively small sample size as well as short-term learning activities. This prevents us from making inferences about a larger population or a long-term program with a given confidence level. These limitations should be addressed in future larger-scale studies. When engaging with mobile devices to learn a foreign language, teachers, learners, and curriculum designers are encouraged to maximize mobile learning benefits and minimize any downsides that mobile devices and mobile interaction may have in the teaching and learning processes. 


\section{References}

[1] Vishwakarma, A. (2015). Benefits and Challenges of Mobile Learning in Education. In Promoting Active Learning through the Integration of Mobile and Ubiquitous Technologies, 24-36. http://doi.org/10.4018/978-1-4666-6343-5.ch001. https://doi.org/10.4018/978-14666-6343-5.ch002

[2] Alrasheedi, M. and Capretz, L. F. (2015). Determination of Critical Success Factors Affecting Mobile Learning: A Meta-Analysis Approach. Turkish Online Journal of Educational Technology - TOJET, 14(2), 41-51. http://www.tojet.net/articles/v14i2/1426.pdf

[3] Jackson, E. A., Sc, B., Gardens, A., and Da, K. (2016). M-Learning devices and their impact on postgraduate researchers' scope for improved integration in the research community. The Online Journal of New Horizons in Education, 6(1), 104-113.

[4] UNESCO. (2013). Policy Guidelines for Mobile Learning. 7, place de Fontenoy, 75352 Paris 07 SP, France. Trad. Representação da UNESCO no Brasil. Retrieved from http://unesdoc. unesco.org/images/0021/002196/219641E.pdf. https://doi.org/10.22452/mjpva.vol1no1.9

[5] Cavus, N. and Ibrahim, D. (2017). Learning English using children's stories on mobile devices. British Journal of Education Technology, 48, 625-641. Retrieved from https://doi. org/10.1111/bjet.12427

[6] Sun, D., Lin, C. H., You, J., Shen, H. J., Qi, S., and Luo, L. (2017). Improving the Englishspeaking skills of young learners through mobile social networking. Computer Assisted Language Learning, 30, 304-324. https://doi.org/10.1080/09588221.2017.1308384

[7] Tingir, S., Cavlazoglu, B., Caliskan, O., Kokklu, O., and Intepe-Tingir, S. (2017). Effects of mobile devices on K-12 students' achievement: A meta-analysis. Journal of Computer Assisted Learning (33)4, 355-369. Retrieved from https://doi.org/10.1111/jcal.12184

[8] Papadakis, St. (2020). Robots and Robotics Kits for Early Childhood and First School Age. International Journal of Interactive Mobile Technologies (iJIM) 14(18), 34-56. https://doi. org/10.3991/ijim.v14i18.16631

[9] Alkhunzain, A. S. (2019). An Empirical Study on Smartphone Addiction of the University Students. International Journal of Interactive Mobile Technologies (iJIM) 13(12), 184. https://doi.org/10.3991/ijim.v13i12.11120

[10] Yazawa, O. (2017). Students' Perception of Native English-Speaking Teachers and Japanese Teachers of English: The Effect on Students' Self-Efficacy and Emotional State. Edit 3(1) (Guest Article), 61-72.

[11] Tran, P. (2016). Training learners to use Quizlet vocabulary activities on mobile phones in Vietnam with Facebook. The JALT CALL Journal, 12(1), 43-56. https://doi.org/10. 29140/jaltcall.v12n1.201

[12] Nguyen, T. and Yukawa, T. (2019), "Kahoot with Smartphones in Testing and Assessment of Language Teaching and Learning, the Need of Training on Mobile Devices for Vietnamese Teachers and Students," International Journal of Information and Education Technology (4)9, 286-296. https://doi.org/10.18178/ijiet.2019.9.4.1214

[13] Lai, M. W. C. (2007). The influence of learner motivation on developing autonomous learning in an English-for-Specific-Purposes course. Master's thesis, The University of Hong Kong, Hong Kong. Asian EFL Journal. Retrieved from http://www.asian-efl-journal.com/thesis lai conttia.pdf. https://doi.org/10.5353/th b3871361

[14] Dörnyei, Z. (2009). Individual Differences: Interplay of Learner Characteristics and Learning Environment. In NC. Ellis \& D. Larsen-Freeman (ed.), Language as a Complex Adaptive System. Oxford: Wiley-Blackwell, 230-248. 
[15] Ushioda, E. (2013). Motivation and ELT: Looking Ahead to the Future. In E. Ushioda (ed.) International Perspective on Motivation, 233-239. https://doi.org/10.1057/9781137000873 $\underline{13}$

[16] Agawa, T. and Ueda, M. (2013). How Japanese Students Perceive Demotivation toward English Study and Overcome such Feelings. JACET Journal 56, 1-18.

[17] Kikuchi, K. (2015). Demotivation in Second Language Acquisition: Insights from Japan. Bristol, UK: Multilingual Matters.

[18] Papadakis, S. (2020). Tools for evaluating educational apps for young children: a systematic review of the literature. Interactive Technology and Smart Education. https://doi.org/10. $\underline{1108 / \text { itse-08-2020-0127 }}$

[19] Papadakis, S., Vaiopoulou, J., Kalogiannakis, M., and Stamovlasis, D. Developing and Exploring an Evaluation Tool for Educational Apps (ETEA). Targeting Kindergarten Children. Sustainability 2020, 12, 4201. https://doi.org/10.3390/su12104201

[20] John, S. P. (2015). The Integration of Information Technology in Higher Education: A Study of Faculty's Attitude towards IT Adoption in the Teaching Process. Contaduría Y Administración 60, 230-252. https://doi.org/10.1016/j.cya.2015.08.004

[21] Elaish, M. M., Shuib, L., Ghani, N. A., and Yadegaridehkordi, E. (2017). Mobile English Language Learning (MELL): a literature review, Educational Review, DOI: https://doi. org/10.1080/00131911.2017.1382445

[22] Lee, C., Yeung, A. S., and Ip, T. (2016). Use of Computer Technology for English Language Learning: Do Learning Styles, Gender, and Age Matter? Computer Assisted Language Learning 29 (5): 1033-1049. https://doi.org/10.1080/09588221.2016.1140655

[23] Nomass, B. B. (2013). The Impact of Using Technology in Teaching English as a Second Language. English Language and Literature Studies 3(1), 111-116. https://doi.org/10. 5539/ells.v3n1p111

[24] Chapelle, C. A. and Sauro S., eds. (2017): The Handbook of Technology and Second Language Teaching and Learning. New Jersey: John Wiley \& Sons.

[25] Eppard, J., Hojeij, Z., Ozdemir-Ayber, P., Rodjan-Helder, M., and Baroudi, S. (2019). Using mobile learning tools in higher education: A UAE Case. International Journal of Interactive Mobile Technologies (iJIM) 13(11), 51-69. https://doi.org/10.3991/ijim.v13i11.10823

[26] Khan, R. M. I., Radzuan, N. R. M., Alkhunaizan, A. S., Mustafa, G., and Khan, I. (2019). The efficacy of MALL instruction in business English learning. International Journal of Interactive Mobile Technologies (iJIM) 13(8), 60-73. https://doi.org/10.3991/ijim.v13i08. $\underline{9562}$

[27] Sockett, G. and Toffoli, D. (2012). Beyond learner autonomy: A dynamic systems view of the informal learning of English in virtual online communities. ReCALL 24(2), 138-151. Retrieved from https://doi.org/10.1017/s0958344012000031

[28] Hafner, C. A. and Miller, L. (2018). Creating spaces for learning: Structure and agency in EST course design. In G. Murray \& T. Lamb (Eds.), Space, Place and autonomy in language learning (pp. 162-178). London, England: Routledge. https://doi.org/10.4324/9781317 220909-11

[29] Kukulska-Hulme, A., Lee, H., and Norris, L. (2017). Mobile learning revolution: Implications for language pedagogy. In C. A. Chapelle \& S. Sauro (Eds.), The handbook of technology and second language teaching and learning (pp. 217-233). Hoboken, NJ: Wiley-Blackwell. Retrieved from http://oro.open.ac.uk/50366/. https://doi.org/10.1002/9781118914069. ch15

[30] Stockwell, G. (2010). Using mobile phones for vocabulary activities: Examining the effect of platform. Language Learning and Technology (4)2, 95-110. 
[31] Guy, R. (2010). Mobile learning: Pilot projects and initiatives. Santa Rosa, Califonia: Informing Science Press, pp. 9-26.

[32] Melhuish, K. and Falloon, G. (2010). Looking to the future: M-learning with the iPad. Computers in New Zealand Schools: Learning, Leading, Technology, 22(3).

[33] Stockwell, G. (2007). Vocabulary on the move: Investigating an intelligent mobile phonebased vocabulary tutor. Computer Assisted Language Learning, 20(4), 365-383. https://doi. org/10.1080/09588220701745817

[34] Stockwell, G. and Liu, Y. C. (2015). Engaging in mobile phone-based activities for learning vocabulary: An investigation in Japan and Taiwan. Calico Journal, 32(2), 299. https://doi. org/10.1558/cj.v32i2.25000

[35] Wan. (2013). Conceptualising mLearning literacy. International Journal of Mobile and Blended Learning (IJMBL), 5(1), 1-20.

[36] Selwyn, N. and Bulfin, S. (2016). "Exploring School Regulation of Students' Technology Use - Rules That Are Made to Be Broken?" Educational Review 68, 274-290, https:// doi.org/10.1080/00131911.2015.1090401

[37] Rimma, I., Andrey I., and Zhanna N. (2020). Application of Mobile Technologies in Foreign Language Learners' Project Activity. International Journal of Interactive Mobile Technologies (iJIM), 21(14), 64-77. https://doi.org/10.3991/ijim.v14i21.18471

[38] Galina, V. and Yuliya, T. (2020). Educational Experience in the Mobile Learning Environment: Consumer Behaviour Perspective. International Journal of Interactive Mobile Technologies (iJIM), 21(14), 92-106. https://doi.org/10.3991/ijim.v14i21.18441

[39] Nunnally, J. C. (1978), Psychometric Theory. New York: McGraw-Hill.

[40] Sarah, L. (2011). Q Skills for Success, Level 1: Reading and Writing (Q: Skills for Success). Oxford: Oxford University Press.

[41] Jaimie, S. (2011). Q Skills for Success, Level 1: Listening and Speaking (Q: Skills for Success). Oxford: Oxford University Press.

[42] Guo, M. and Wang, M. (2018). Integrating WeChat-based Mobile-Assisted Language Learning into College English Teaching. EAI Endorsed Transactions on E-Learning, 5(17), 1-12. https://doi.org/10.4108/eai.25-9-2018.155646

[43] Qian, K. and Tang, J. (2018). Researching mobile-assisted English language learning among adult distance learners in China: Emerging practices and learner perception of teacher role. International Journal of Computer-Assisted Language Learning and Teaching, 8(3), 1-28. https://doi.org/10.4018/978-1-7998-1757-4.ch012

[44] Ushioda, E. and Dörnyei, Z. (2017). Beyond Global English: Motivation to Learn Languages in a Multicultural World: Introduction to the Special Issue. The Modern Language Journal, 101(3), 451-454. https://doi.org/10.1111/modl.12407

[45] Amiri, E. and Branch, L. (2012). A study of the application of digital technologies in teaching and learning English language and literature. International Journal of Scientific \& Technology Research, 1(5), 103-107.

[46] Ghavifekr, S. and Rosdy, W. A. W. (2015). Teaching and learning with technology: Effectiveness of ICT integration in schools. International Journal of Research in Education and Science (IJRES), 1(2), 175-191. https://doi.org/10.21890/ijres.23596

[47] Drossel, K., Eickelmann, B., and Gerick, J. (2017) 'Predictors of teachers' use of ICT in school - the relevance of school characteristics, teachers' attitudes and teacher collaboration', Education and Information Technologies, 22(2), 551-573. https://doi.org/10.1007/ s10639-016-9476-y

[48] Papadakis, S. (2020). Apps to Promote Computational Thinking Concepts and Coding Skills in Children of Preschool and Pre-Primary School Age. In Mobile Learning Applications in 
Early Childhood Education (pp. 101-121). IGI Global. https://doi.org/10.4018/978-1-79981486-3.ch006

[49] Domingo, M. G. and Gargante, A. B. (2016) 'Exploring the use of educational technology in primary education: Teachers' perception of mobile technology learning impacts and applications' use in the classroom', Computers in Human Behavior, 56, 21-28. https://doi. org/10.1016/j.chb.2015.11.023

[50] Papadakis, S., \& Kalogiannakis, M. (2020). A research synthesis of the real value of selfproclaimed mobile educational applications for young children. Mobile learning applications in early childhood education, 1-19. https://doi.org/10.4018/978-1-7998-1486-3.ch001

[51] Drolia, M., Sifaki, E., Papadakis, S., \& Kalogiannakis, M. (2020). An Overview of Mobile Learning for Refugee Students: Juxtaposing Refugee Needs with Mobile Applications' Characteristics. Challenges, 11(2), 31. https://doi.org/10.3390/challe11020031

\section{$7 \quad$ Authors}

Nguyen Thi Thanh Thuy is currently doing a Ph.D. in educational technology and teaching English for specific purposes. Her research interests include methodologies in teaching English as a foreign language for special purposes, integrating information and communication technologies (ICT) into teaching and learning languages, testing and assessing learners' outcomes with computer-assisted or mobile devices.

Takashi Yukawa is a professor at the Nagaoka University of Technology, majoring in computer-supported collaborative learning and e-learning. His studies focus on integrating information and communication technologies (ICT) into education, testing and assessing learners' outcomes with computer-assisted or mobile devices.

Article submitted 2020-11-22. Resubmitted 2021-02-05. Final acceptance 2021-02-05. Final version published as submitted by the authors. 